\section{In vitro studies on periodontal ligament cells and enamel matrix derivative}

\author{
Gestrelius S, Andersson C, Lidström D, Hammarström L, Somerman M: In vitro
} studies on periodontal ligament cells and enamel matrix derivative. $J$ Clin Periodontol 1997; 24: 685-692. (C) Munksgaard, 1997.

Abstract. The recognition that periodontal regeneration can be achieved has resulted in increased efforts focused on understanding the mechanisms and factors required for restoring periodontal tissues so that clinical outcomes of such therapies are more predictable than those currently being used. In vitro models provide an excellent procedure for providing clues as to the mechanisms that may be required for regeneration of tissues. The investigations here were targeted at determining the ability of enamel matrix derivative (EMD) to influence specific properties of periodontal ligament cells in vitro. Properties of cells examined included migration, attachment, proliferation, biosynthetic activity and mineral nodule formation. Immunoassays were done to determine whether or not EMD retained known polypeptide factors. Results demonstrated that EMD under in vitro conditions formed protein aggregates, thereby providing a unique environment for cell-matrix interaction. Under these conditions, EMD: (a) enhanced proliferation of PDL cells, but not of epithelial cells; (b) increased total protein production by PDL cells; (c) promoted mineral nodule formation of PDL cells, as assayed by von Kossa staining; (d) had no significant effect on migration or attachment and spreading of cells within the limits of the assay systems used here. Next, EMD was screened for possible presence of specific molecules including: GM-CSF, calbindin D, EGF, fibronectin, bFGF, $\gamma$-interferon, IL- $1 \beta, 2,3$, 6; IGF1,2 ; NGF, PDGF, TNF, TGF $\beta$. With immunoassays used, none of these molecules were identified in EMD. These in vitro studies support the concept that EMD can act as a positive matrix for cells at a regenerative site.

\section{Stina Gestrelius', Christer Andersson', Dagny Lidström?, Lars Hammarström ${ }^{2}$ and Martha Somerman ${ }^{3}$}

${ }^{1}$ BIORA AB, Maimö, Sweden, ${ }^{2}$ Center for Oral Biolagy, Karolinska institute, Stockholm, Sweden, 'Department of Periodontics/Prevention/ Geriatrics and Department of Pharmacology, University of Michigan, Ann Arbor, MI, USA
Key words: enamel proteins; immunoassay; proliteration, attachment, biosynthesis, mineral Accepted for publication 25 March 1997
Periodontal diseases are marked by inflammation and subsequent loss and/or damage to tooth-supporting tissues, including cementum, periodontal ligament (PDL) and bone. Increasing evidence that tissues of the periodontium harbour cells with the capacity to regenerate the periodontium has fostered an interest in developing clinical procedures to restore periodontal support by promoting such cells to function in a regenerative capacity, i.e., formation of new cementum, periodontal ligament and new bone (Hammarström 1996, MacNeil et al. 1995, Pitaru et al. 1994, McCulloch 1993, Aukhil et al. 1990,
Nanci et al. 1996). Logical candidates for stimulating cells at the healing site to function in a regenerative capacity are proteins in their local environment, in particular extracellular matrix proteins.

An approach used to determine which proteins may be involved in regeneration of specific tissues is to first examine the tissues of interest during developmental stages. While it is recognized that regeneration does not follow exactly the pattern required during development of a given tissue, there are many similarities between the 2 processes. Thus, using histology, immuno- histochemistry, in situ hybridization and tissue recombination experiments one can determine the temporal and spatial distribution of specific cells and their associated proteins during formation of a given tissue. Information obtained by such investigations provides clues as to which proteins may be required for altering cellular behaviour, e.g., migration, attachment, proliferation and cell differentiation, as required for inducing regeneration of tissues. In particular, with regard to oral tissues, it is now recognized that epithelial-mesenchymal interactions are required for formation of enamel 
(ameloblasts) and dentin (odontoblasts) (Thesleff et al. 1996). These inductive interactions can result from cell-cell interactions, from interactions between extracellular matrix molecules and cell surface receptors and/or from diffusible signals such as growth factors during crown development (Vainio et al. 1993).

With regard to cementum, Slavkin \& Boyde (1975) and Slavkin (1976) proposed that similar interactions occur between dental ectomesenchymal cells (follicle cells) and cells of the Hertwig epithelial root sheath. In this situation they suggested that enamel related proteins from the root sheath initiate formation of cementum. Studies over the past twenty years support this hypothesis (for review, see Hammarström (1997)), and studies by Hammarström (1997) and Hammarström et al. (1997) demonstrated that enamel matrix is involved in the formation of acellular cementum during tooth development, and that this matrix has the potential to induce regeneration of acellular cementum in experimental periodontal defects in monkeys.

To further explore the role for enamel matrix proteins in periodontal regeneration, the effect of enamel matrix derivative (EMD) on PDL cells in vitro was examined. EMD contains purified hydrophobic amelogenins, which form insoluble aggregates ("matrix") under physiological conditions. Specific cellular behaviours examined were cell migration, attachment, proliferation and biosynthetic activity and included formation of mineralized nodules. All these are events known to be required for promoting development as well as regeneration of periodontal tissues. In addition, since extracellular matrices may have the capacity to bind and retain polypeptides, it was important to determine whether or not EMD contained any serum associated factors, such as growth factors and adhesion molecules, that may contribute to the observed biological events.

\section{Material and Methods \\ Proteins and polypeptides}

\section{Enamel matrix derivative}

Enamel matrix derivative (EMDOGAIN ${ }^{\circledR}$ ), was obtained from BIORA AB, Malmö, Sweden. For in vitro studies, lyophilized protein was added to the medium as an aqueous solution ( $\mathrm{pH}$ 5-6). Alternatively, wells or dishes were first coated by allowing an alkaline
EMD solution (carbonate buffer $\mathrm{pH}$ 10) to incubate overnight (attachment assays and mineralizations assays).

\section{Reference polypeptides}

(a) Radiolabelled ( ${ }^{125} \mathrm{I}$ )

bFGF (human, IM 243), spec. activity $1000 \mu \mathrm{Ci} / \mathrm{nmol}$, Amersham. UK

EGF (human, IM 196), spec. activity $1300 \mu \mathrm{Ci} / \mathrm{nmol}$, Amersham, UK

IGF-1 (human, IM 172), spec. activity $1900 \mu \mathrm{Ci} / \mathrm{nmol}$, Amersham, UK

IGF-2 (human, IM 238), spec. activity $2000 \mu \mathrm{Ci} / \mathrm{nmol}$, Amersham, UK

PDGF BB homodimer (human, IM 213), spec. activity $1000 \mu \mathrm{Ci} / \mathrm{nmol}$, Amersham, UK

IL-3 (human, IM 220), spec. activity $600 \mu \mathrm{Ci} / \mathrm{nmol}$, Amersham, UK

GM-CSF (human, IM 224), spec. activity $1200 \mu \mathrm{Ci} / \mathrm{nmol}$, Amersham, UK

IFN-gamma (human, IM 202), spec. activity $600 \mu \mathrm{Ci} / \mathrm{nmol}$, Amersham, UK

NGF (murine, IM 207), spec. activity $1500 \mu \mathrm{Ci} / \mathrm{nmol}$, Amersham, UK

TGFB1(human, NEX 267), spec. activity $3000 \mu \mathrm{Ci} / \mathrm{nmol}$, DuPont, Germany TGFB1 (human, IM 246), spec. activity $2284 \mu \mathrm{Ci} / \mathrm{nmol}$, Amersham. UK

(b) Unlabelled

bFGF (bovine, BDP 13), British Biotech, UK

TGFB1.2 (porcine platelets, lot R811), R\&D Systems, UK

TGFB1(human, TG010), Chemicon, USA

TGFB1 (human), from Quantikine ELISA kit (DB 100), R\&D Systems, UK

\section{Antibodies}

\section{Anti-EMD}

Polyclonal anti-EMD was raised in rabbits by repeated injections of EMD in Freund's adjuvant. The rabbits were immunized and blood was collected during a period of 4-6 months. Pooled whole serum was also purified by affinity chromatography using EMD bound ( $6 \mathrm{mg} \mathrm{EMD} / \mathrm{ml}$ gel) to Sepharose 4B (Pharmacia, Uppsala, Sweden) in phosphate buffered saline (PBS), and stepwise eluted with $1 \mathrm{M} \mathrm{NaCl}$ and 0.2 M 2-aminobutane $\mathrm{pH} 11$. Eluted antibody fraction was desalted using $\mathrm{Se}-$ phadex G-25sf (Pharmacia, Uppsala, Sweden) and diluted to $25 \mu \mathrm{g} / \mathrm{ml}$, as analysed with HPLC (Superdex 75) at $215 \mathrm{~nm}$ with human IgG used for calibration. The whole serum and the affinity purified antibody recognized EMD in immunoradiometric assays at a dilution of $1: 10^{6}$ and $1: 10^{5}$, respectively.
Antibodies to polypeptide factors and

proteins

IGF-1 RIA-kit IM.1721, Amersham, UK

PDFG RIA-kit RPA.536, Amersham, UK

TNF RIA-kit RPA.532, Amersham, UK

$I L-1 \beta$ RIA-kit RPA.533, Amersham, UK

IL-2 ELISA kit, Genzyme Corporation, USA

IL-6 ELISA kit, Genzyme Corporation, USA

FGF basic ELISA kit RPN 2158, Amersham, UK

$T G F-\beta_{1}$, Quantikine ELISA kit (DB $100)$, R\&D Systems, UK

$T G F-\beta_{2}$, ELISA kit RPN 2163, Amersham, UK

Anti-FGF basic (bovine, BDA4), pure IgG, British Biotech, UK

Anti-TGFB (porcine, BDAl), British Biotech, UK

Anti-fibronectin (human, MAB042), Chemicon, USA

Anti-calbindin D (chicken, C-8666), Sigma, USA

\section{Cell cultures and media}

Human PDL cells

Human periodontal ligament cells (PDL cells) were obtained from healthy human periodontal tissues of individuals undergoing extractions of premolars for orthodontic reasons. Details for growing such cells have been published (Somerman et al. 1988a). Cells were used between passage 4 and 10

\section{In vitro assays with human PDL cells}

\section{Attachment assays}

The attachment assay used was a modification of Klebe (1974) (Somerman et al. 1989). The dishes were either precoated with the protein or the dishes were preincubated with DMEM $+0.1 \%$ BSA and EMD for $1 \mathrm{~h}$ prior to the addition of the cells. For these assays attachment activity was evaluated at $1.5 \mathrm{~h}$ to $6 \mathrm{~h}$. Photographs were taken to evaluate spreading and then cells were removed enzymatically and counted electronically using a Coulter Counter.

\section{Chemotaxis (migration) assay}

In order to determine the ability of cells to move directionally toward extracts of EMD in vitro, a Boyden Chamber system was used (Somerman et al. 1989, 1982 as modified from Postlethwaite et 
al. 1976). For these studies both PDI cells and CRL 1475 foreskin fibroblasts were used. CRL 1475 are known to have a marked chemotactic response to fibronectin (Somerman et al. 1989) whereas PDL cells have less of an ability to migrate to a chemoattractant (unpublished data). EMD in DMEM/1\% BSA was added to the bottom chamber at $5,25,50$ and $100 \mu \mathrm{g} / \mathrm{ml}$, a millipore polycarbonate filter $(8 \mu \mathrm{m}$ pore sizeprecoated with gelatin) was placed over this solution and then cells in DMEM containing $1 \mathrm{mg} / \mathrm{ml}$ BSA were placed in the upper chamber. Chambers were incubated at $37^{\circ} \mathrm{C}$ for $4 \mathrm{~h}$, then filters were removed, stained with Hemacolor (Diagnostic Systems Inc, Gibbstown. NJ, USA) and transferred to slides. Cells attached to the upper surface were removed and cells migrating through the filter determined by counting a 1 $\mathrm{mm}^{2}$ microscopic field per filter.

Proliferation assay (cell toxicity assay) Proliferation rate was carried out over a 10-day period, so as to provide information on both cell proliferation and cell toxicity. About 5000 cells were seeded into test wells in DMEM/10\% FBS with antibiotics and allowed to attach for $24 \mathrm{~h}$. After cells attach, medium was removed and replaced with DMEM/ 10\% FBS (positive control); $2 \%$ FBS DMEM (negative control) or $2 \%$ FBS DMEM plus EMD at 25, 50 or $100 \mu \mathrm{g}$ $\mathrm{ml}$. Under standard protocol medium is changed on days 3, 6 and 9 (Somerman et al. 1988b); however, in order to control the amount of EMD aggregate in the wells, media were not changed. Triplicate wells were harvested on days 1 , 2, 4, 7 and 10 and cell counting performed by Coulter Counter. Statistical tests were performed with analysis of variance (ANOVA) and Duncan's multiple range test.

\section{Biosynthesis assays}

Total protein/collagen. Cells in DMEM/ $10 \%$ FCS and antibiotics were exposed to $\operatorname{EMD}(25,50,100 \mu \mathrm{g} / \mathrm{ml})$ for $48 \mathrm{~h}$ and labelled with $\mathrm{L}\left[5-{ }^{3} \mathrm{H}\right]$-proline $(10$ $\mu \mathrm{Ci} / \mathrm{ml})$ to determine total protein and collagen (Somerman et al. 1988). Cells and media were pooled, dialysed extensively against buffer and samples counted by liquid scintillation spectrometer. These counts were used to measure total protein production. Concurrent with assays for protein production, cultures were prepared to determine cell proliferation and thus results were normalized to cell number. To estimate collagen production, an aliquot of the dialysed material was reacted for $6 \mathrm{~h}$ with bacterial collagenase (Peterkofsky \& Diegelmann 1971). Resulting proteins were precipitated with TCA-tannic acid, and the supernatant and a control supernatant were counted by scintillation spectrometer. Thus, counts from collagenase-treated sample minus control sample represented collagen production. Statistical tests were performed with ANOVA and Duncan's multiple range test.

Electrophoresis. Pooled media and cell samples were dialysed against water and lyophilized, then dissolved in SDSPAGE buffer, where concentration of sample used was corrected for cell number. Thus any variation in protein profiles found is based on increased protein production per cell when evaluated by gel electrophoresis. After reduction with mercaptoethanol the protein samples were analysed by electrophoresis on SDS $4-20 \%$ polyacrylamide gradient slab gels according to the method of Laemmli (1970). The stacking gel was $4 \%$ acrylamide. The gels were fixed, dried and autoradiographed by the method of Bonner \& Laskey (1974).

\section{Mineralization assays}

PDL cells were cultured in $175 \mathrm{~cm}^{2}$ flasks (Nunclon, Nunc, Denmark) in $\alpha$ MEM supplemented with $10 \%$ calf serum, antibiotics (Penicillin-Streptomycin). L-glutamine and ascorbic acid (50 $\mu \mathrm{g} / \mathrm{ml})$. After 10 days, the cells were trypsinized, counted and plated on EMD-coated Petri dishes. Attempts to decrease the serum concentration from 10 to $5 \%$ resulted in very low cloning efficiencies and thus cells were maintained in $10 \%$ FCS. Appropriate controls included cells seeded on EMD with mineralization enhancers, dexamethasone (10 $\mathrm{nM})$ and $\beta$-glycerophosphate (10 $\mathrm{mM}$ ), added (Tenenbaum \& Heersche 1982), and cells not cultured on EMD matrix plus or minus dexamethaxone and $\beta$-glycerophosphate. PDL cells $(50,100$ or 200 in $1 \mathrm{ml}$ solution), treated as described above, were plated and incubated at $37^{\circ} \mathrm{C}$ in a humidified atmosphere of $95 \%$ air and $5 \% \mathrm{CO}_{2}$ for 7 days before the first change of medium. Fresh medium was then supplied twice weekly. Von Kossa assay (Von Kossa, 1901, as described by Bancroft \& Stevens, 1990) was used to determine presence of mineral nodules and was performed 15-30 days after cultivation, most typically after 21-22 days. Mineral nodules were examined microscopically and the number of stained clones, as well as the total number of clones, were counted. Classification was performed according to the following system.

Type I, very dense clones; Type $I$, dense clones but without merged filaments; and Type $I I I$, diffuse clones.

Statistical tests on impact of different concentrations and additives were performed with one-way analysis of variance using SPSS/PC+, version 4.01.

\section{Immunoassays}

\section{Immunoradiometric assay (IRMA)}

Coated substances were detected by double antibody technique. The second (labelled) antibody was either goat antirabbit IgG (for EMD, bGFG and TGFB) or goat anti-mouse IgG (for calbindin and fibronectin), and radioactivity was measured using a gamma counter (LKB Wallac 1275, Stockholm, Sweden).

\section{Radioimmunoassay (RIA)}

Radiolabelled polypeptides were detected by a double antibody technique using anti-EMD plus Pharmacia Decanting System 3 (sheep anti-rabbit antibody). About 100 fmol of radiolabelled polypeptide was added per tube, resulting in a detection limit of 2-10 fmol ( $\approx 5 \%$ bound tracer).

\section{Commercial kits ( RIA or ELISA)}

Commercial kits were used according to the Package Insert. ELISA microtiter plates were analysed using Milenia equipment (Diagnostic Products Corp., Los Angeles, CA, USA). The Multicalc evaluation program (version 2.0, Wallac, Stockholm, Sweden) was used for calculating the standard curves and results. The detection limits were set at ten times the coefficient of variation of a buffer blank.

Four different TGF $\beta$ standards were fractionated on a HPLC column (Superdex 75, Pharmacia, Sweden) equilibrated in 3\% acetic acid, $30 \%$ acetonitrile and $0.9 \% \mathrm{NaCl}$. All fractions were concentrated by vacuum centrifugation, and PBS with $0.1 \%$ BSA and $0.1 \%$ Tween was added to the original volume. $\mathrm{pH}$ was adjusted to 5.6 with $\mathrm{NaOH}$. Each fraction was then tested with the Quantikine test for activated TGF $\beta$ (analytical range $31-2000 \mathrm{pg}$ / ml). In parallel, EMD alone or EMD 


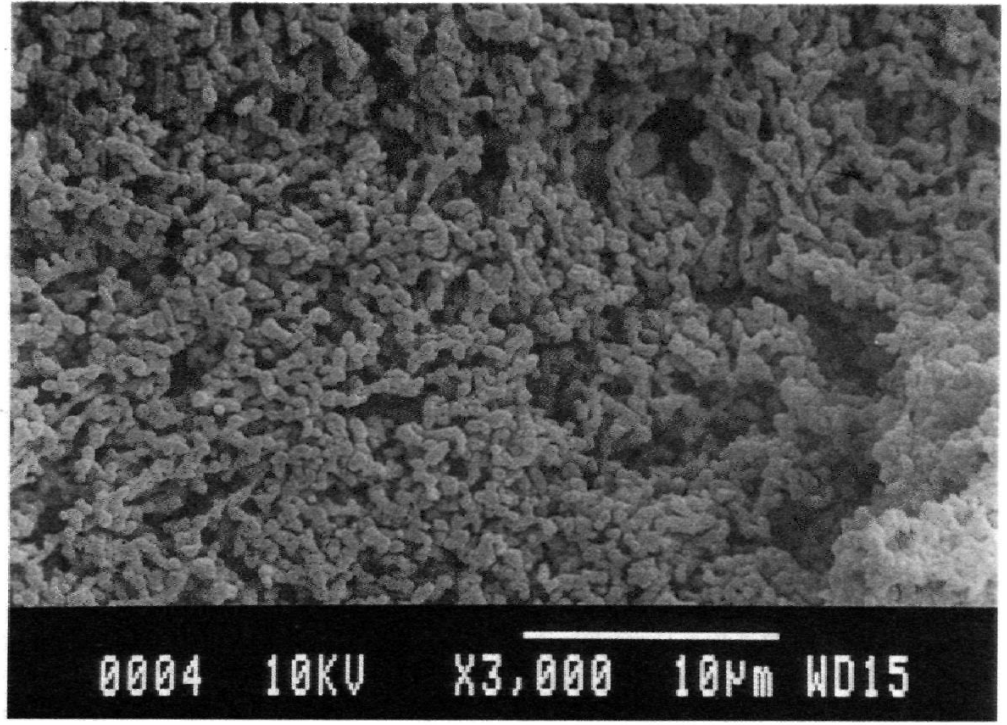

Fig. 1. Enamel matrix derivative (EMD) precipitated from aqueous solution. Scanning electron micrograph. Bar $=100 \mu \mathrm{m}$,

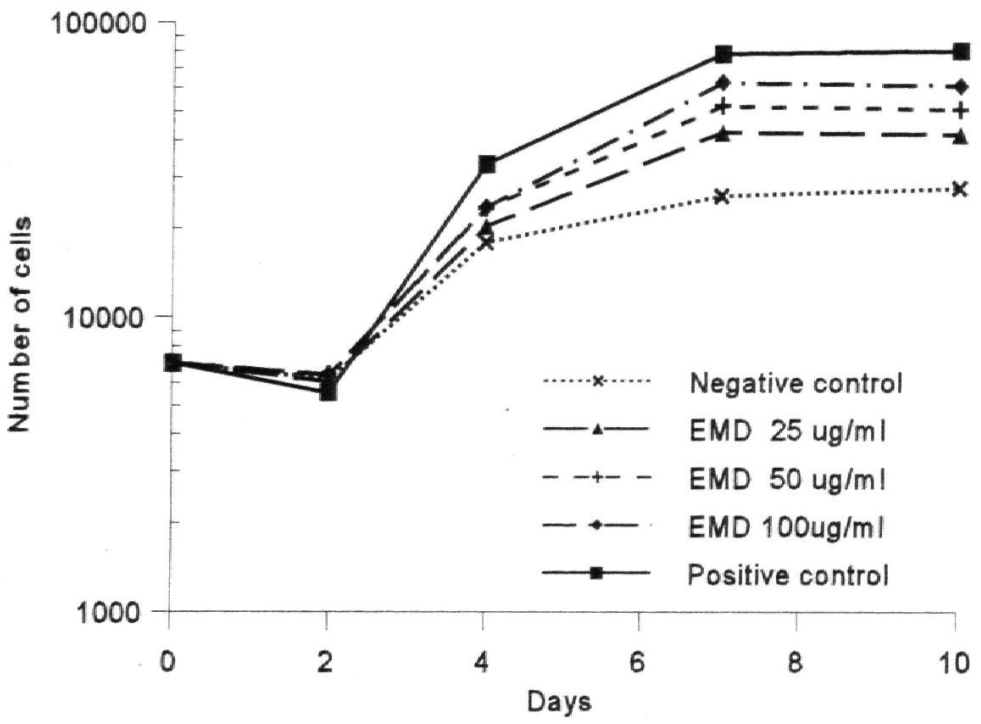

Fig. 2. Proliferation of PDL cells exposed to EMD. PDL cells were allowed to attach overnight prior to addition of EMD at $25 \mu \mathrm{g} / \mathrm{ml}(\mathbf{\Delta}) 50 \mu \mathrm{g} / \mathrm{ml} \mathrm{(+)}$ and $100 \mu \mathrm{g} / \mathrm{ml}(\bullet)$. Cells exposed to $2 \%$ FCS (x) served as a negative control, while cells exposed to $10 \%$ FCS (E) served as a positive control. At days 2, 4, 7 and 10, using triplicate wells, cells were trypsinized and counted by Coulter counter. Shown here is a representative experiment where results were reproduced in three separate experiments. Data evaluated by ANOVA and Duncan's multiple range test indicated that EMD enhanced cell proliferation as follows:

$\begin{array}{clrl}\text { Day 2: } 2 \% \text { FCS, EMD } & \text { - subset I } & \text { Days 7, 10: } 2 \% \text { FCS } & \text { - subset I } \\ 10 \% \text { FCS } & \text { - subset II } & \text { EMD } 25 \mu \mathrm{g} / \mathrm{ml} & \text { - subset II } \\ \text { Day 4: } 2 \% \text { FCS } & \text { - subset I } & \text { EMD } 50 \mu \mathrm{g} / \mathrm{ml} & \text { - subset III } \\ \text { EMD } 25 \mu \mathrm{g} / \mathrm{ml} & \text { - subset II } & \text { EMD } 100 \mu \mathrm{g} / \mathrm{ml} \text { - subset IV } \\ \text { EMD } 50 \mu \mathrm{g} / \mathrm{ml}, 100 \mu \mathrm{g} / \mathrm{ml} & \text { - subset III } & 10 \% \text { FCC } & \text { - subset V } \\ 10 \% \text { FCS } & \text { - subset IV } & & \end{array}$

mixed with TGF $\beta$ standard was fractionated using the same procedure and tested with the same kit.

\section{Results}

In vitro assays with human PDL cells

\section{Attachment and chemotactic activity}

For adhesion assay uncoated wells were pre-incubated for $1 \mathrm{~h}$ with DMEM plus EMD or fibronectin (positive control) or uncoated wells were pre-coated with these agents. Cells were added for $1.5 \mathrm{~h}$ to $6 \mathrm{~h}$. Under both assay conditions, EMD enhanced cell attachment to a minimal degree at $20 \mu \mathrm{g} / \mathrm{ml}$, but did not promote cell spreading during this time period, i.e., the cells remained rounded but viable. In contrast, cells exposed to fibronectin were attached and spread by $1 \mathrm{~h}$.

Next, the ability of PDL cells to migrate to EMD was tested using a Boyden chamber assay. Under the conditions and doses used EMD produced no enhancement of cell migration and this was repeated in three separate experiments (data not shown).

\section{Proliferation}

When an acidic solution of EMD was added to the cell culture medium a protein aggregate was formed. As seen in Fig. 1, this appeared as an accumulation of microspheres with a diameter of about $1 \mu \mathrm{m}$. In order not to alter the quantity of EMD these assays were performed without change of culture media. EMD. added at baseline, influenced cell proliferation, with a small increase after 4 days and a marked enhancement seen after 7 or 10 days, Fig. 2.

Next, to establish whether or not this enhancement was selective to PDL cells. the effect of EMD on proliferative activity of epithelial cells was investigated. Using the same protocol as for PDL cells but with rat tongue epithelium, derived from explant cultures of rat ventral mucosa, no difference was observed in proliferation between cells exposed to EMD and control cells over the 10 day period, Fig. 3. Similar results were noted for HT 1080 cells, a cell line that exhibits epithelial-like characteristics including expression of keratins (data not shown).

\section{Biosynthetic activity \\ When preattached cells were exposed to EMD and ${ }^{3} \mathrm{H}$-proline for $48 \mathrm{~h}$, the pro- duction of total protein and collagen was enhanced up to the level observed}




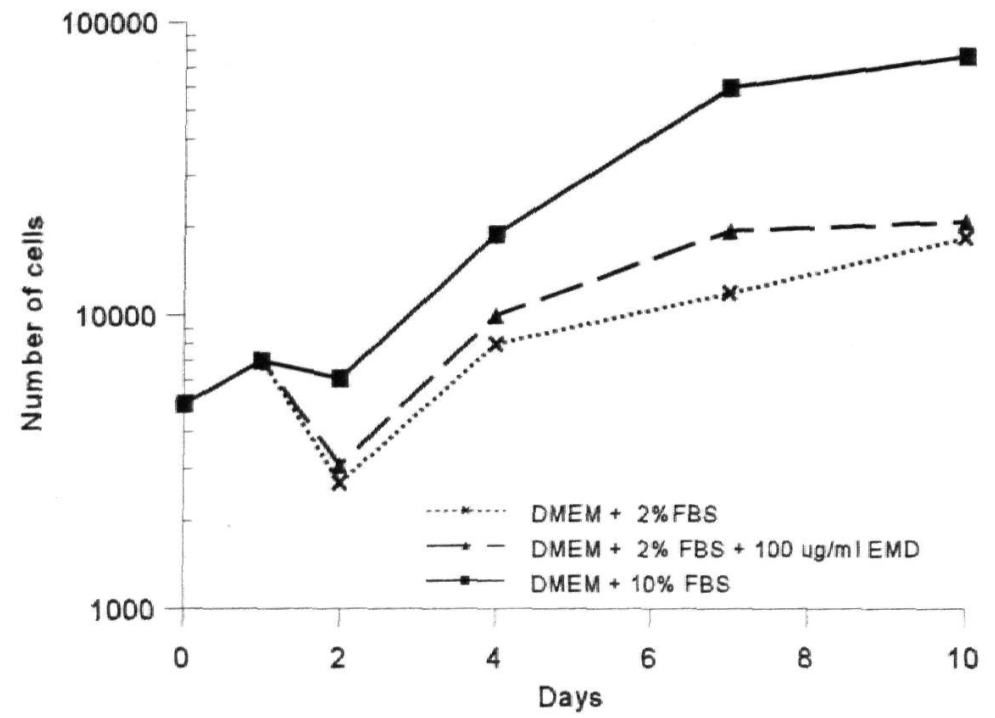

Fig. 3. Proliferation of rat tongue epithelial cells exposed to EM. Cells were allowed to attach overnight prior to addition of EMD, $100 \mu \mathrm{g} / \mathrm{ml}(\mathbf{\Delta})$. Cells exposed to $2 \%$ FCS $(X)$ served as negative control, while $10 \%$ FCS (- served as a positive control. Cells in triplicate wells, at days 2, 4, 7 and 10, were trypsinized and counted by Coulter counter. Data analysis using ANOVA and Duncan's multiple range test, show that EMD fits in the same subset as 2\% FCS, indicating that EMD had no effect beyond control at any time point.

Table 1. Relative protein production by $\mathrm{PDL}$ cells exposed to EMD in the presence of ${ }^{3} \mathrm{H}$ proline for $48 \mathrm{~h}$

\begin{tabular}{lcc}
\hline Treatment & $\begin{array}{c}\text { Protein } \\
\text { (ratio treated/control) }\end{array}$ & $\begin{array}{c}\text { Collagen } \\
\text { (ratio treated/control) }\end{array}$ \\
\hline negative control (no additive) & $1.00 \pm 0.03$ & $1.00 \pm 0.09$ \\
EMD & $2.06 \pm 0.20^{*}$ & $1.83 \pm 0.23^{*}$ \\
$25 \mu \mathrm{g} / \mathrm{ml}$ & $2.34 \pm 0.24^{*}$ & $1.95 \pm 0.29^{*}$ \\
$50 \mu \mathrm{g} / \mathrm{ml}$ & $2.60 \pm 0.15^{*}$ & $2.44 \pm 0.15^{*}$ \\
$100 \mu \mathrm{g} / \mathrm{ml}$ & $2.48 \pm 0.18^{*}$ & $2.32 \pm 0.08^{*}$ \\
\hline
\end{tabular}

\# Dentin is a guanidine/EDTA extract of bovine dentin.

* Triplicate results were significant compared to the control as demonstrated by the ANOVA Duncan multiple range test:

Protein:

No additon-subset I:

$25 \mu \mathrm{g} / \mathrm{ml}$ EMD- subset II.

$50 \mu \mathrm{g} / \mathrm{ml} \mathrm{EMD}$, dentin extract - subset III

$100 \mu \mathrm{g} / \mathrm{ml}$ EMD, dentin extract - subset IV

for the positive control $(100 \mu \mathrm{g} / \mathrm{ml}$ guanidine/EDTA extract of dentin), as is seen in Table 1. From the results it does not appear that EMD enhanced collagen production more than other types of proteins, i.e., there was an increase in total protein production. Autoradiographic examination of the protein profile for cells exposed to EMD vs. dentin extract $(\mathrm{G} / \mathrm{E}-\mathrm{D})$ revealed several bands in common (Fig. 4). For example, intense banding noted in the $100-200 \mathrm{kDa}$ region with both 1987a) and this band was not apparent in cells exposed to EMD.

\section{In vitro mineralization model}

Cloning efficiencies, reflected as the total number of clones in medium with $10 \%$ serum, were around $30 \%$ both in the presence and absence of additives such as EMD or dexamethasone plus $\beta$-glycerophosphate (Table 2). Examples of the different types of clones are shown in Fig. 5. The morphology varied with the additives, showing the highest number of very dense clones, Type $I$, in the presence of $\beta$-glycerophosphate and dexamethasone. An increased number of Type $I I$ clones were found in the presence of EMD. The most striking difference noted from treatment with EMD, however, was seen as the frequency of clones that were von Kossa stained. This increased fivefold from the control to a frequency of about $25 \%$ in the presence of EMD. Addition of $\beta$-glycerophosphate and dexamethasone to the control increased the frequency of von Kossa stained clones to about $15 \%$. As a contrast, the mineralization enhancers only added marginally to the establishment of nodules, in the presence of EMD. Thus, the presence of EMD, even in the absence of mineralization enhancers, resulted in a significantly higher number of von Kossa stained clones compared to the negative control as well as compared to the positive control.

EMD was used at an amount of $30 \mu \mathrm{g}$ $\mathrm{ml}$ and the effect on von Kossa-stained clones was found to increase both in the presence and in the absence of dexamethasone. The addition of dexamethasone appeared to induce mineralization at an earlier time point, as seen from results on days 16-17 compared with those on days 21-22, but did not increase the final ratio of von Kossa-stained clones. Precipitation of EMD aggregate was noticed on the dishes and the fibroblasts appeared to grow in close association with the protein aggregate. While in these studies we did not examine the association of mineral modules with collagen fibrils, it has been shown previously that PDL cells, isolated as those used here, will form mineral-collagen associated nodules (Arceo et al. 1991).

However, there was one region between $46-69 \mathrm{kDa}$, where the banding pattern appeared different between these two agents (Fig. 4: bracket region). In addition, cells exposed to G/E-D exhibited an intense banding in the region around $100 \mathrm{kDa}$ (Fig. 4., arrow), as reported previously (Somerman et al.

\section{Immunoanalytical tests}

For this study 3 sensitive methods were selected and a number of analyses performed.

In method I, commercial antibodies 


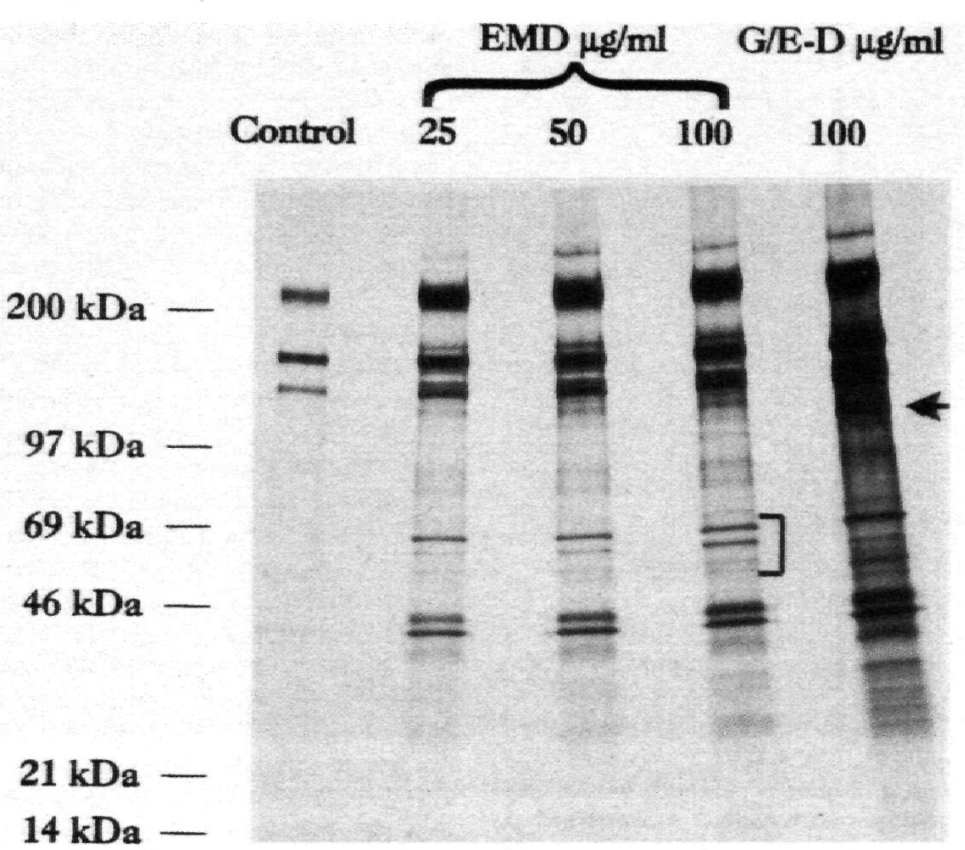

Fig. 4. Autoradiograph of SDS-PAGE from ${ }^{3} \mathrm{H}$-proline labelled PDL cells exposed to EMD or dentin extract. Cells were either untreated (control) or treated with EMD at 25, 50 or 100 $\mu \mathrm{g} / \mathrm{ml}$ or guanidine/EDTA extract of dentin (G/E-D) at $100 \mu \mathrm{g} / \mathrm{ml}$ for $48 \mathrm{~h}$ as described in methods section. Each pooled medium and cell sample having equal cell numbers was dialyzed against water, lyophilized and dissolved in gel buffer and loaded at $50 \mu \mathrm{g} / \mathrm{lane}$. Thus, any variation in protein profiles found was based on increased protein production per cell. $\leftarrow$ points to intense band, $100 \mathrm{kDa}$ region noted in G/E-D treated cells but not in control or EMD treated cells. I demonstrates area where protein profile differences are suggested between cells exposed to EMD versus $G / E-D$ and where banding reflects an EMD effect on protein production.

to polypeptide factors and proteins were exposed to EMD solution. The detection limits were found to be $10-300$ $\mathrm{pg} / \mathrm{ml}$ by testing with reference peptides. None of the antibodies tested reacted with EMD (Table 3).

In method II, anti-EMD serum produced by Biora was exposed to commercial polypeptides. This antiserum would contain antibodies to growth factors, if any were present in EMD. A reaction be- tween anti-EMD and a factor would indicate the presence of the factor in EMD. The detection limits varied from $100 \mathrm{pg} /$ $\mathrm{ml}$ up to $1-5 \mathrm{ng} / \mathrm{ml}$. By radioimmunoassay (RIA) it was shown that anti-EMD did not react with any of the 12 factors/ proteins tested (Table 3 ).

In method III, EMD was tested for interaction with an immobilized TGF $\beta_{2}$ receptor (Quantikine test) and a positive reaction was found, even without
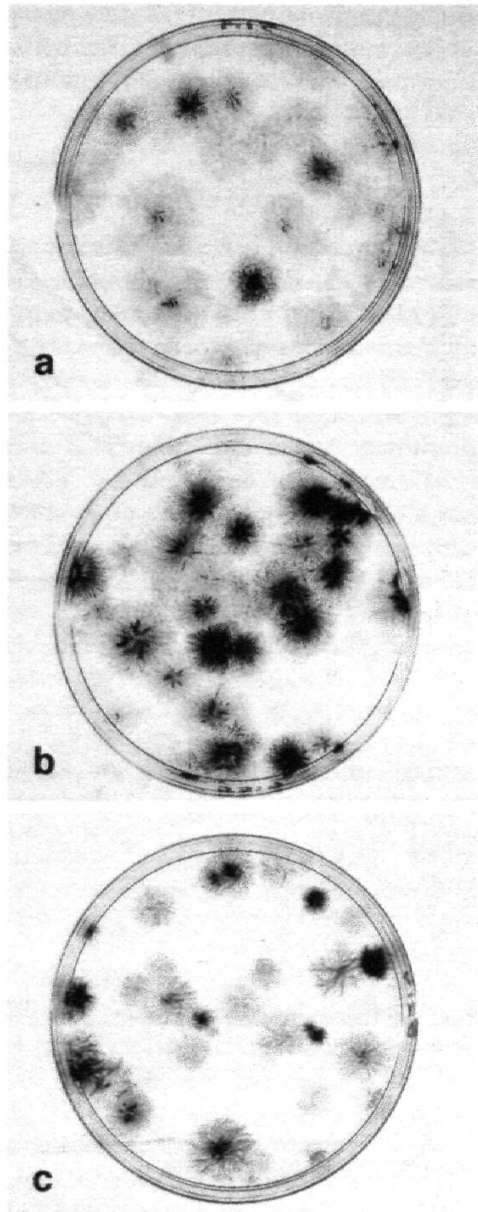

Fig. 5. Human PDL cell clones that have been von Kossa stained after 22 days (cf. Table 2). (A) shows a negative control, without additives; (B) has been cultured on EMD $(30 \mu \mathrm{g} / \mathrm{ml})$ added from start and at change of media; $(\mathrm{C})$ is a positive control with addition of $10 \mathrm{nM}$ dexamethasone plus $10 \mu \mathrm{M} \beta$-glycerophosphate from start and with new media.

Table 2. Formation of mineral nodules by PDL cells exposed to EMD; frequencies of Von Kossa stained clones and dense clones (Types I and II)

\begin{tabular}{|c|c|c|c|c|c|c|c|c|c|c|}
\hline \multirow[b]{3}{*}{ Treatment } & \multicolumn{5}{|c|}{ 16-17 days } & \multicolumn{5}{|c|}{ 21-22 days } \\
\hline & \multirow{2}{*}{$\begin{array}{c}\text { Von } \\
\text { Kossa } \\
(\%)\end{array}$} & \multicolumn{2}{|c|}{$\begin{array}{l}\text { clones } \\
\% \text { of total }\end{array}$} & \multirow{2}{*}{$\begin{array}{l}\text { total } \\
\text { clones } \\
\text { (I-III) }\end{array}$} & \multirow[b]{2}{*}{$n$} & \multirow{2}{*}{$\begin{array}{c}\text { Von } \\
\text { Kossa } \\
(\%)\end{array}$} & \multicolumn{2}{|c|}{$\begin{array}{l}\text { clones } \\
\% \text { of total }\end{array}$} & \multirow{2}{*}{$\begin{array}{c}\text { total } \\
\text { clones } \\
\text { (I-III) }\end{array}$} & \multirow[b]{2}{*}{$n$} \\
\hline & & I & II & & & & 1 & II & & \\
\hline negative & 2 & 0 & 7 & 38 & 5 & 5 & $<1$ & 13 & 31 & 15 \\
\hline EMD $30 \mu \mathrm{g} / \mathrm{ml}$ & $10^{*}$ & 0 & 9 & 34 & 6 & $23^{* *}$ & 1 & $26^{*}$ & 35 & 18 \\
\hline positive control ${ }^{\#}(\operatorname{Dex} / \beta \mathrm{GP})$ & 4 & 3 & 11 & 35 & 6 & $14 *$ & $5^{*}$ & 15 & 31 & 15 \\
\hline $\mathrm{EMD}^{+}$ & $19 *$ & 9* & $16^{*}$ & 35 & 4 & $25 * *$ & $4^{*}$ & $26^{*}$ & 29 & 4 \\
\hline
\end{tabular}

\# Positive control is $10 \mathrm{nM}$ dexamethasone and $10 \mathrm{mM}$-glycerophosphate.

* Significantly different from the negative control demonstrated by ANOVA.

** Significantly different from the positive control demonstrated by ANOVA. 
Table 3. Immunoassays for polypeptides in Enamel Matrix Derivative (EMDOGAIN ${ }^{\circledR}$ )

\begin{tabular}{|c|c|c|c|c|c|}
\hline Analysis & $\begin{array}{l}\text { MW (kDa) } \\
\text { of peptide } \\
\text { or protein }\end{array}$ & $\begin{array}{l}\text { Detection } \\
\text { limit } \\
(\mathrm{ng} / \mathrm{ml})\end{array}$ & $\begin{array}{c}\text { Method I } \\
\text { (anti-peptide } \\
\text { versus EMD) }\end{array}$ & $\begin{array}{c}\text { Method II } \\
\text { (anti-EMD } \\
\text { versus } \\
\text { polypeptide) }\end{array}$ & Test \\
\hline GM-CSF & 22 & 0.5 & - & $<$ & RIA \\
\hline calbindin $\mathrm{D}$ & 28 & 1 & $<$ & - & IRMA \\
\hline EGF & 6 & 0.1 & - & $<$ & RIA \\
\hline fibranectin & -500 & 1 & $<$ & - & $\begin{array}{c}\text { IRMA } \\
\text { IRMA }\end{array}$ \\
\hline bFGF & 18 & $1,0.5,0.01$ & $<$ & $<$ & ELISA \\
\hline$y$-Interferon & 40 & 1 & - & $<$ & RIA \\
\hline IL- $1 \beta$ & 17 & 0.1 & $<$ & - & RIA \\
\hline $\mathrm{IL}-2$ & 15.5 & 0.3 & $<$ & - & ELISA \\
\hline IL-3 & 20 & 0.5 & - & $<$ & RIA \\
\hline IL-6 & 26 & 0.3 & $<$ & - & ELISA \\
\hline IGF-1 & 7.7 & $5 ; 0.1$ & $<$ & $<$ & RIA \\
\hline IGF-2 & 7.7 & 0.1 & - & $<$ & RIA \\
\hline NGF & 30 & 0.5 & - & $<$ & RIA \\
\hline PDGF & 30 & $2 ; 0.5$ & $<$ & $<$ & RIA \\
\hline TNF & 17 & 0.2 & $<$ & - & RIA \\
\hline TGF $-\beta$ & 25 & $1: 0.1$ & $<$ & $<$ & IRMA, RIA \\
\hline TGF- $\beta 2$ & 25 & $0.02 ; 0.1$ & $<$ & $<$ & ELISA, RIA \\
\hline
\end{tabular}

$<$ denotes that the result is below the detection limit.

Abbreviations used: GM-CSF macrophage colony stimulating factor; EGF epidermal growth factor; bFGF basic fibroblast growth factor; IL interleukin; IGF insulin like growth factor; NGF nerve growth factor; PDGF platelet derived growth factor: TNF tumour necrosis factor, TGF transforming growth factor.

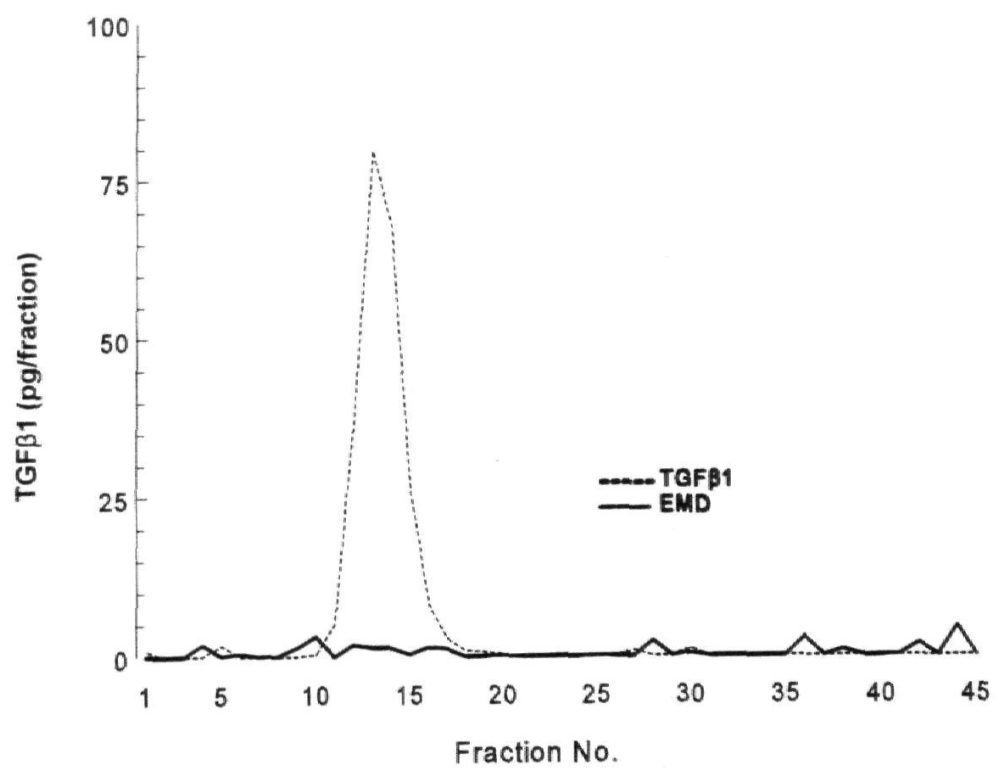

Fig. 6. Test for activated TGF $\beta 1$ (Quantikine) on fractions from size exclusion chromatography (Superdex 75$)$ of EMD $(55 \mu \mathrm{g})$ or TGF $\beta$ reference $(500 \mathrm{pg})$. After separation the fractions were concentrated and dissolved as described in the Methods section.

preactivation. This reaction was questioned since EMD had visibly precipitated in all wells, as expected at the physiological conditions used, and since none of the immunoassays using dards were fractionated on the same column and again all fractions were tested. As seen from Fig. 6, all fractionated TGF $\beta$ standards were detected but none of the EMD fractions unless $\mathrm{TGF} \beta$ had been added, indicating that a false positive result had been observed due to precipitation of EMD.

\section{Discussion}

The results of the in vitro studies further contributed to the understanding of the mechanisms by which EMD may play a role in promoting cementum formation and periodontal regeneration. The stimulation of cellular proliferation and protein and collagen production and formation of mineralized nodules in PDL cell cultures exposed to EMD are compatible with the regeneration results obtained in vivo (Hammarström et al. 1997). When interpreting the results obtained in vitro it should be kept in mind that EMD is insoluble at the $\mathrm{pH}$ and temperature at which the studies were performed (Gestrelius et al. 1997). A visible protein aggregate was noted when EMD was added to cell culture media at concentrations of $5 \mu \mathrm{g}$ $\mathrm{ml}$ or more. This motivated the design of the proliferation and protein synthesis studies, i.e., no change of culture medium was done. Thus, the results could be explained by EMD being a viable matrix for cells and/or the result of a cell-matrix interaction. This is analogous to the normal in vivo environment where most cells require an extracellular matrix in order to function (Clark, 1995). In addition, while no polypeptide factors were detected in EMD, there is a possibility that growth factors from the medium itself or from the medium conditioned by the cells were taken up by the EMD aggregates and thereby enhanced the bioactivity of the cells.

The studies on cell attachment indicated that dishes coated with EMD were well accepted by the PDL cells, but this matrix had a minimal effect on cell attachment or cell spreading. When compared with the effects of fibronectin, one of the known attachment proteins, the effect of EMD was markedly less and very much slower in development. EMD contains no known attachment sequences (BIORA AB/data on file) and the slight increased attachment is more likely caused by added media or substances produced by the PDL cells rather than a direct effect of EMD. 
The Boyden chamber experiments, which measure the response of cells to a soluble chemical gradient, showed no response to EMD. Future studies on cell migration to surface-bound adhesion gradient (heptataxis) are required to further explore the migratory behaviour of cells in response to EMD.

As discussed above, the increase in cell proliferation and biosynthetic activity in PDL cells exposed to EMD could be explained by the suitable three dimensional substratum provided. In addition, the assays were carried out with a single addition of EMD and cells were maintained in the same medium for up to 10 days, thus the enhancement of proliferation, protein production and mineralization seen over time may well have been caused by endogenous cellular products.

Interestingly, the response of epithelial cells to the addition of EMD differed from that of the PDL cells. The lack of enhanced proliferation of the epithelial cells is in agreement with the results obtained in the in vivo dehiscence experiments in monkeys, in which epithelial down-growth was very limited when EMD was applied on the root surface (Hammarström et al. 1997). The mechanism(s) behind the different responses by epithelial and mesenchymal cells is presently not known.

In conclusion, the addition of EMD to cell culture media resulted in a number of changes, which included enhanced proliferation of the PDL cells as well as increased protein and collagen production and promotion of mineralization. In contrast, addition of EMD had no significant effect on epithelial cell proliferation in vitro. No growth factors could be detected in EMD. The current data thus support the hypothesis that EMD can act as a matrix for cells at a periodontal regenerative site. Specifically, the results suggest that aggregates formed by EMD at physiological $\mathrm{pH}$ and temperature are responsible for creating a positive environment for cells to proliferate and differentiate, as required for regeneration of the periodontium. Clearly, future studies are required in order to determine the exact mechanisms by which EMD may influence cell function, in vitro and in vivo.

\section{References}

Arceo, N., Sauk, J. J., Moehring, J., Foster, R. A. \& Somerman, M. J. (1991) Human periodontal cells initiate mineral-like nod- ules in vitro. Journal of Periodontology 62, 499-503.

Aukhil, I. Nishimura, K. \& Fernyhough, W. (1990) Experimental regeneration of the periodontium. Critical Reviews in Oral Biology and Medicine 1, 101-105.

Bancroft, J. D. \& Stevens, A. (1990) Theory and practice of histological techniques, 3rd edition. Churchill Livingstone, pp 324. 333-334.

Bonner, W. M. \& Laskey, R. A. (1974) A film detection method for tritium labelled proteins and nucleic acids in polyacrylamide gels. European Biochemical Journal 46, 8388.

Clark, A. F. (1995) Molecular and cellular biology of wound healing, 2nd edition.

Gestrelius, S., Persson, E., Johansson, A. C., Andersson, C., Brodin. A., Rydhag. L. \& Hammarström, L. (1997), Formulation of enamel matrix derivative for surface coating. Kinetics and cell colonization. Journal of Clinical Periodontology 24, 678-684.

Hammarström, L. (1996) The role of enamel matrix proteins in the development of cementum and periodontal tissues. In 1997 Dental enamel Wiley, Chichester (Ciba Foundation Symposium 205), p. 246-260.

Hammarström, L. (1997), Enamel matrix, cementum development and regeneration. Journal of Clinical Periodontology 24, 658 668.

Hammarström, L.. Heijl, L. \& Gestrelius, S. (1997), Periodontal regeneration in a buccal dehiscence model in monkeys after application of enamel matrix proteins. Journal of Clinical Periodontology 24, 669 677.

Kossa, J. von (1901), Nachweis von Kalk. Beitrage zur pathologischen Anatomie und zur allgemeinen Pathologie 29, 163.

Klebe, R. (1974) Isolation of a collagen-dependent cell attachment factor. Nature $250,248-253$

Laemmli, V. (1970) Cleavage of structural proteins during assembly of the head of bacteriophage $\mathrm{T}_{4}$. Nature 227, 680-685.

McCulloch, C. A. G. (1993) Basic considerations in periodontal wound healing to achieve regeneration Periodontology 2000 1, 16-25.

MacNeil, R. L., Berry, J., D'Errico, J., Strayhorn, C. \& Somerman, M. (1995), Localization and expression of osteopontin in mineralized and nonmineralized tissues of the periodontium. In: Denhardt, D. T., Butler, W. T., Chambers, A. F. \& Singer, D. R. (eds): ANYAS Osteopontin: Role in cell signaling and adhesion 760, 166-176.

Nanci, A., McKee, M. D., Smith, C. E., (eds) The Anatomical Record 245: 1996 Special Issue: The biology of dental tissues.

Peterkofsky, V. \& Diegelmann, R. (1971) Use of a mixture of proteinase-free collagenases for the specific assay of radioactive collagen in the presence of other proteins. Biochemistry 10, 988-994.

Pitaru, S., McCulloch, C. A. G. \& Narayanan, S. A. (1994) Cellular origins and differentiation control mechanisms during peri- odontal development and wound healing Journal of Periodontal Research 29, 81-94.

Postlethwaite, A. E., Snyderman, R. \& Kang, A. H. (1976) Chemotactic attraction of human fibroblasts to a lymphocyte-derived factor. Journal of Experimental Medicine 144, 1188-1203.

Slavkin, H. C. \& Boyde, A. (1975) Cementum: An epithelial secretory product? Journal of Dental Research 53, 157 (abstr $\# 409$ ).

Slavkin, H. C. (1976) Towards a cellular and molecular understanding of periodontics: Cementogenesis revisited. Journal of Periodontology 47, 249-255.

Somerman, M. J., Schiffmann, E., Reddi, A H. \& Termine, J. (1982) Regulation of the attachment and migration of bone cells, in vitro. Journal of Periodontal Research 17, $527-529$

Somerman, M. J., Archer, S. Y., Hassel, T M. \& Foster, R. A. (1987a) Enhancement by extracts of mineralized tissues of protein productivity by human gingival fibroblasts, in vitro. Archives of Oral Biology 32, 879-883.

Somerman. M. J., Archer, S. Y., Sheyeter, A. \& Foster, R. A. (1987b) Protein production by human gingival fibroblasts is enhanced by guanidine EDTA extracts of cementum, in vitro. Journal of Periodontal Research 22, 75-77.

Somerman, M. J., Archer, S. Y., Imm, G. R. \& Foster, R. A. (1988a) A comparative study of human periodontal ligament cells and gingival fibroblasts in vitro. Journal of Dental Research 67, 66-70.

Somerman, M. J., Foster, R. A., Vorsteg, G. Progebin, K. \& Wynn, R. L. (1988b) Effects of minocycline on fibroblast attachment and spreading. Journal of Periodontal Research 23, 154-159

Somerman. M. J., Prince, C. W., Butler, W. T., Foster, R. A., Moehring, J. M. \& Sauk. J. J. 1989) Cell attachment activity of the 44 kilodalton bone phosphoprotein is not restricted to bone cells. Matrix 9, 49-54.

Tenenbaum, H. C. \& Heersche, J. N. M. (1982) Differentiation of osteoblasts and formation of mineralized bone in vitro. Calcified Tissues International 34, 76-79.

Thesleff, I. (1996) Molecular mechanisms of cell and tissue interactions during early tooth development. The Anatomical Record 245, 151-161.

Vainio, S., Karavanova, I., Jowett, A. \& Thesleff, I. (1993) Identification of BMP-4 as a signal mediating secondary induction between epithelial and mesenchymal tissues during tooth development. Cell $\mathbf{7 5}$, 45-58.

\section{Address:}

Stina Gestrelius

BIORA $A B$

Ideon/Malmö

S-205 12 Malmö, Sweden

Tel.: +4640321330

Fax: +4640321355

e-mail: stina.gestrelius@biora.se 
This document is a scanned copy of a printed document. No warranty is given about the accuracy of the copy. Users should refer to the original published version of the material. 